\title{
Model Fuzzy Mamdani Untuk Penilaian Tingkat Kepuasan Pelayanan Pengaduan Masyarakat
}

\author{
Martin ${ }^{1}$, Lala Nilawati ${ }^{2}$, \\ ${ }^{1}$ STMIK Nusa Mandiri Jakarta \\ e-mail: martin.auf@gmail.com \\ ${ }^{2}$ AMIK BSI Jakarta \\ e-mail: Iala.Ini@bsi.ac.id
}

\begin{abstract}
Abstrak
Kualitas pelayanan adalah salah satu keunggulan kompetitif, karena pelayanan yang baik adalah salah satu faktor dasar yang mampu mempengaruhi tingkat kenyamanan penerima layanan. Pelayanan publik oleh aparatur pemerintah dewasa ini masih banyak dijumpai kelemahan, sehingga belum dapat memenuhi kualitas yang diharapkan masyarakat. Penelitian ini ditujukan untuk melihat seberapa besar kepuasan pelayanan, dan pengaruh tingkat pelayanan terhadap tingkat kepuasan berdasarkan Logika Fuzzy Inference System Model Mamdani. Ada empat variabel input yang digunakan yaitu kejelasan informasi, kejelasan persyaratan, kemampuan petugas dan ketersediaan sarana dan prasarana untuk menghasilkan output kepuasan pelayanan. Berdasarkan tahapan-tahapan menggunakan Logika Fuzzy Inference System Model Mamdani mulai dari pembentukan himpunan fuzzy, aplikasi fungsi impilkasi, komposisi aturan sampai proses penegasan (defuzzyfikasi), dapat dibuktikan adanya korelasi antara variabel-variabel input sehingga dapat menentukan output hasil kepuasan pelayanan. Hasil penelitian ini diharapkan dapat digunakan oleh pihak instansi, sebagai pendukung sistem keputusan terhadap hasil penilaian yang diberikan oleh masyarakat untuk pelayanan yang dirasakan. Pengembangan penelitian ini kedepan nya akan diuji coba kembali dengan menambahkan lebih banyak variabel dan akan dibuat sebuah interface untuk memudahkan pemprosesan hasil penilaian kualitas pelayanan pengaduan masyarakat.
\end{abstract}

Kata Kunci: Pelayanan, Fuzzy Mamdani, Logika Fuzzy.

\begin{abstract}
Service quality is one of the competitive advantages, because good service is one of the basic factors that can affect the comfort level of service recipients. Public services by the government apparatus today are still often found to be weak, so that they cannot meet the quality expected by the community. This study is intended to see how much service satisfaction is, and the effect of service levels on satisfaction levels based on Mamdani Model Fuzzy Inference System Logic. There are four input variables used namely clarity of information, clarity of requirements, ability of officers and availability of facilities and infrastructure to produce service satisfaction output. Based on the stages using Mamdani Model Fuzzy Inference System Logic starting from the formation of fuzzy sets, application of the implementation function, composition of the rules until the confirmation process (defuzzyfication), it can be proved the correlation between input variables so that it can determine the output of service satisfaction. The results of this study are expected to be used by the agency, as a support system for the decision on the results of the assessment given by the community for perceived services. The future development of this research will be re-tested by adding more variables and an interface will be created to facilitate the processing of the results of the quality assessment of public complaints services.
\end{abstract}

Keywords: Service, Fuzzy Mamdani, Fuzzy Logic.

\section{Pendahuluan}

Kualitas pelayanan yang baik di suatu Instansi merupakan faktor dasar yang mampu mempengaruhi tingkat kenyamanan. Dalam mengontrol kualitas pelayanan dimasa yang akan datang, maka diperlukan kualitas pelayanan untuk mencegah terjadinya kualitas pelayanan yang jelek sejak awal (FC \& Lisnawita, 2017). Kualitas layanan dipandang sebagai 
salah satu alat untuk mencapai keunggulan kompetitif, karena kualitas layanan merupakan salah satu faktor yang menentukan pilihan yang dapat memuaskan penerima layanan (Jusia \& Yani, 2017)

Komisi Nasional Hak Asasi Manusia (Komnas HAM) merupakan lembaga mandiri, yang kedudukannya setingkat dengan lembaga negara lainnya yang berfungsi melaksanakan fungsi pengkajian, penelitian, penyuluhan, pemantauan dan mediasi. Bagian Dukungan Pelayanan Pengaduan (DPP) adalah unit kerja yang memiliki fungsi dan wewenang menerima pengaduan tentang pelanggaran HAM yang terjadi diindonesia. Bagian ini menjadi sangat strategis karena menghubungkan antara komnas HAM dengan publik, atau pun sebaliknya dan boleh dikatakan sering disebut sebagai garda terdepan pengemban amanat konsep pelayanan publik di Komnas HAM.

Pelayanan publik oleh aparatur pemerintah dewasa ini masih banyak dijumpai kelemahan, sehingga belum dapat memenuhi kualitas yang diharapkan masyarakat. Hal ini ditandai dengan masih adanya berbagai keluhan masyarakat yang disampaikan melalui media massa, sehingga dapat menimbulkan citra yang kurang baik terhadap aparatur pemerintah. Mengingat fungsi utama pemerintah adalah melayani masyarakat maka pemerintah perlu terus berupaya meningkatkan kualitas pelayanan (KEP/25/M.PAN/2/2004, 2004).

Pelaksanaan pelayanan pengaduan ini, apabila disesuaikan dengan Reformasi Birokrasi maka harus diselenggarakan secara professional, prima, efisien dan efektif, artinya harus tepat sasaran. Oleh karena itu, saran dan kritik dari stakeholders sangat diperlukan sebagai upaya peningkatan kualitas pelayanan pengaduan. Tujuan penelitian ini diharapkan dapat mengetahui kelemahan atau kekurangan dari masing-masing unsur dalam penyelenggaraan pelayanan pengaduan, dapat mengetahui kinerja penyelenggara pelayanan pengaduan HAM yang dilaksanakan oleh Bagian DPP, serta melihat seberapa besar kepuasan pelayanan dan pengaruh tingkat pelayanan terhadap tingkat kepuasan berdasarkan Logika Fuzzy Inference System Model Mamdani.

\section{Kepuasan Pelayanan}

Kepuasan adalah perasaan senang atau kecewa seseorang yang muncul setelah membandingkan antara persepsi/kesannya terhadap kinerja (atau hasil) suatu produk dan harapanharapannya. Kepuasan kerja merupakan fungsi dari persepsi/kesan atas kinerja dan harapan. Jika kinerja berada dibawah harapan, pelanggan tidak puas. Jika kinerja memenuhi harapan, pelanggan puas. Jika kinerja melebihi harapan, pelanggan amat puas (Kotler, 2003).

Gagliano dalam Wiratno mengatakan bahwa "Kualitas pelayanan (Service Quality) adalah pandangan konsumen terhadap hasil perbandingan antara ekspektasi konsumen dengan kenyataan yang diperoleh dari pelayanan (Wiratno, 1998). Sedangkan kepuasan adalah persepsi pelanggan terhadap satu per satu pengalaman layanan yang diterima (Cronin \& Taylor, 1992).

Pengertian kepuasan pelayanan dalam Keputusan Menteri Pendayagunaan Aparatur Negara Nomor KEP/25/M.PAN/2004 adalah hasil pendapat dan penilaian masyarakat terhadap kinerja pelayanan yang diberikan oleh aparatur penyelenggara pelayanan publik. Kepuasan publik sangat erat kaitannya dengan kualitas pelayanan yang diberikan. Menurut Williams dan Buswell mengatakan bahwa, "Satisfaction is a psycological outcome emerging from an experience, whereas service quality is concerned with the atributes of service it self' (Williams \& Buswell, 2003).

Atribut-atribut yang mempengaruhi kepuasan pelanggan terhadap pelayanan yang diselenggarakan oleh sebuah organisasi, dapat dilihat dari sisi persepsi pelanggan dan dari sisi harapan pelanggan. Berdasarkan prinsip pelayanan sebagaimana telah ditetapkan dalam Keputusan Menteri Pendayagunaan Aparatur Negara Nomor $\mathrm{KEP} / 25 / \mathrm{M} . \mathrm{PAN} / 2004$, yang kemudian dikembangkan menjadi 14 unsur yang relevan, valid, dan reliable, sebagai unsur minimal yang harus ada untuk dasar pengukuran indeks kepuasan masyarakat adalah sebagai berikut:
a. Prosedur pelayanan.
b. Persyaratan Pelayanan.
c. Kejelasan petugas pelayanan.
d. Kedisiplinan petugas pelayanan. 
e. Tanggung jawab petugas pelayanan.

f. Kemampuan petugas pelayanan.

g. Kecepatan pelayanan.

h. Keadilan mendapatkan pelayanan.

i. Kesopanan dan keramahan petugas.

j. Kewajaran biaya pelayanan.

k. Kepastian biaya pelayanan.

I. Kepastian jadwal pelayanan.

m. Kenyamanan lingkungan.

n. Keamanan Pelayanan.

\section{Logika Fuzzi}

Konsep tentang logika fuzzy diperkenalkan oleh Prof. Lotfi Astor Zadeh pada 1962. Logikam fuzzy adalah metodologi sistem kontrol pemecahan masalah yang cocok untuk diimplementasikan pada sistem, mulai dari sistem yang sederhana, sistem kecil, jaringan PC, multi-channel atau workstation berbasis akuisisi data, dan sistem kontrol. Dalam logika fuzzy memungkinkan nilai keanggotaan berada diantara 0 dan 1 (Zadeh, 1975).

Menurut Kusumadewi dan Purnomo menyebutkan "Logika fuzzy merupakan salah satu komponen pembentuk soft computing". Logika fuzzy pertama kali di perkenalkan oleh Prof. Lotfi A. Zaedah pada tahun 1965. Dasar logika fuzzy adalah teori himpunan fuzzy. Pada teori himpunan fuzzy, peranan derajat keanggotaan sebagai penentu keberadaan elemen dalam suatu himpunan sangatlah penting (Kusumadewi \& Purnomo, 2004).

Sutojo, dkk mengatakan "Logika fuzzy adalah metodologi sistem kontrol pemecahan masalah, yang cocok untuk diimplementasikan pada sistem, mulai dari system yang sederhana, sistem kecil, embedded sistem, jaringan PC, multichannel atau workstation berbasis akuisisi data, dan sistem kontrol. Metodologi ini diterapkan pada perangkat keras, perangkat lunak, atau kombinasi keduanya" (Sutojo, Mulyanto, \& Suhartono, 2011).

\section{Logika Fuzzy Inference System Model Mamdani}

Fuzzy Inference System Model Mamdani sering juga dikenal dengan nama metode max-min. Metode ini diperkenalkan oleh Ebrahim Mamdani pada tahun 1975. Metode mamdani sering digunakan dalam aplikasi-aplikasi karena strukturnya yang sederhana, yaitu menggunakan operasi MIN-MAX atau MAX-PRODUK
(Kusumadewi, 2002). Untuk mendapatkan output, diperlukan 4 tahapan yaitu:

a. Pembentukan himpunan fuzzy.

Pada Metode Mamdani, baik variabel input maupun variabel output dibagi menjadi satu atau lebih himpunan fuzzy.

b. Aplikasi fungsi implikasi. Pada Metode Mamdani, fungsi implikasi yang digunakan adalah Min.

c. Komposisi Aturan

Tidak seperti penalaran monoton, apabila sistem terdiri-dari beberapa aturan, maka inferensi diperoleh dari kumpulan dan korelasi antar aturan. Ada 3 metode yang digunakan dalam melakukan inferensi sistem fuzzy, yaitu: max, additive dan probabilistik OR (probor)

d. Penegasan (defuzzyfikası)

Input dari proses defuzzifikasi adalah suatu himpunan fuzzy yang diperoleh dari komposisi aturan-aturan fuzzy, sedangkan output yang dihasilkan merupakan suatu bilangan pada domain himpunan fuzzy tersebut. Sehingga jika diberikan suatu himpunan fuzzy dalam range tertentu, maka harus dapat diambil suatu nilai crips tertentu sebagai output.

\section{Tinjauan Studi}

Penelitian yang dilakukan oleh Nuraida, Iryanto dan Sebayang dengan judul Analisis Tingkat Kepuasan Konsumen Berdasarkan Pelayanan, Harga dan Kualitas Makanan Menggunakan Fuzzy Mamdani dengan Studi Kasus Pada Restoran Cepat Saji CFC Marelan menggunakan perancangan sistem mulai dari pembentukan himpunan Fuzzy, aplikasi fungsi implikasi (pembentukan aturan Fuzzy), komposisi aturan Fuzzy, dan penegasan (defuzzifikasi). Hasil penelitian menunjukan tingkat pelayanan diperoleh bilangan riil 5,5 dengan domain [5 8] yang artinya variabel tingkat pelayanan cukup baik, tingkat harga makanan dengan bilangan riil 5,5 dengan domain [5 8] yang artinya tingkat harga makanan cukup murah, tingkat kualitas makanan diperoleh bilangan riil 5,5 dengan domain [5 8] yang artinya tingkat kualitas makanan cukup berkualitas. Output yang diperoleh yaitu tingkat kepuasan konsumen dengan bilangan riil 6,63 yang artinya konsumen merasa cukup puas dengan pelayanan dan 
harga serta kualitas makanan yang diberikan Restoran cepat saji CFC (Nuraida, Iryanto, \& Sebayang, 2013).

Pada penelitian Putri, dkk mengenai Pengaruh Kepuasan Nasabah Terhadap Pelayanan Teller yang mengambil studi kasus di PT. Bank DKI Cabang Walikota Jakarta Timur menggunakan metode Fuzzy Mamdani, dari hasil pengolahan data-data yang ada dan setelah dianalisis data yang dijadikan sample dapat dikategorikan bahwa keadaan kualitas pelayanan yang dirasakan nasabah secara keseluruhan termasuk dalam kategori baik, dan mencapai tingkat efektivitas berkategori tinggi yang ditunjukan dengan hasil nilai yang didapat adalah 8,5. Selain itu, Kenyamanan nasabah berbanding lurus dengan kualitas pelayanan yang diberikan oleh teller sehingga berpengaruh positif dan signifikan terhadap kinerja pelayanan teller. Dengan penggunaan metode Fuzzy Mamdani menunjukan bahwa Metode Fuzzy Mamdani dapat digunakan dalam menentukan kinerja pelayanan teller terhadap kepuasan nasabah (Putri, Sumanto, Sari, \& Ispandi, 2014).

Hasil penelitian yang dilakukan oleh Lucky Lhaura Van FC dan Lisnawita tentang analisis kepuasan pelanggan terhadap pelayanan purnajual CV. Family menunjukan hasil termasuk dalam kategori puas, dengan dipengaruhi oleh tingkat pelayanan dan harga yang ditawarkan pada jasa yang diberikan dimana tingkat kualitas pelayanan, didapatkan bilangan real sebesar 6.99. Metode yang digunakan adalah aplikasi fuzzy logic, maka analisis terhadap kepuasan pelanggan terhadap tingkat pelayanan $\mathrm{CV}$. Family menunjukan lebih mudah dan cepat (FC \& Lisnawita, 2017).

Jusia dan Yani dalam penelitiannya dengan judul Model Kepuasan Mahasiswa Terhadap Sistem Pelayanan Administrasi Akademik dan Kemahasiswaan, dengan Fuzzy Inference System Metode Mamdani Pada STIKOM Dinamika Bangsa Jambi, didapatkan hasil rancangan model untuk menentukan tingkat kepuasan mahasiswa terhadap sistem pelayanan BAAK, dengan menggunakan logika fuzzy inference system metode mamdani. Pada penelitian ini berdasarkan analisis data kuesioner responden pada STIKOM Dinamika Bangsa Jambi mempunyai lima parameter, yaitu: tangible, responsivenss, realiability, assurance, dan emphaty. Model logika fuzzy inference system metode mamdani yang dibangun berdasarkan parameter rule yang telah ditentukan dapat dibangun dengan software yaitu matlab r2013a (Jusia \& Yani, 2017).

Penelitian Tarigan, Tobing dan Situmorang mengenai Mengukur Tingkat Kepuasan Mahasiswa Terhadap Kinerja Dosen, Menggunakan Metode Fuzzy Mamdani yang dilakukan di STT Poliprofesi Medan menggunkan empat tahapan yaitu penentuan himpunan fuzzy, aplikasi fungsi implikasi, komposisi aturan dan defuzzyfikasi. Berdasarkan tahapantahapan tersebut diperoleh suatu model yang dapat memperlihatkan aturan keterhubungan antara motivasi dosen, persiapan mengajar dosen dan pelaksanaan perkuliahan dengan nilai mahasiswa. Penelitian ini telah menunjukkan korelasi variabel mahasiswa dengan variabel penilai dalam menentukan tingkat kepuasan mahasiswa terhadap kinerja dosen mengajar. (Tarigan, Tobing, \& Situmorang, 2017).

\section{Metode Penelitian}

Studi kasus dalam penelitian ini yaitu mengenai penilaian tingkat kepuasan pelayanan pengaduan masyarakat di Komnas HAM. Jenis data yang digunakan adalah data primer dan sata sekunder. Data Primer yaitu pengumpulan data dengan menjalankan penelitian langsung pada pengadu dalam hal ini masyarakat yang menjadi objek penelitian. Sedangkan untuk Data Sekunder yaitu pengumpulan data dari beberapa literatur dan karya ilmiah yang berhubungan dengan pengolahan dan dan penyusunan hasil penelitian ini.

Teknik pengumpulan data yang dilakukan dengan membagikan daftar pertanyaan-pertanyaan (questionnaire) secara tertulis kepada pengadu dan wawancara (interview) langsung dengan pengadu. Data yang diperoleh kemudian dibagi menjadi data training dan data testing. Selain itu, untuk mendukung peneltian ini Penulis melakukan proses studi pustaka dengan bersumber dari buku maupun jurnal penelitian terdahulu mengenai logika fuzzy, khususnya fuzzy mamdani. Tahapan-tahapan menggunakan logika Fuzzy Inference System Model Mamdani akan dimulai dari pembentukan himpunan fuzzy (Fuzzifikasi), aplikasi fungsi impilkasi, komposisi aturan sampai proses 
penegasan (defuzzyfikasi). (Kusumadewi, 2002)

\section{Hasil dan Pembahasan}

Dalam proses menentukan penilaian tingkat kepuasan pelayanan pengaduan masyarakat akan digunakan empat variabel input dan satu variabel output. Untuk variabel input diantaranya adalah berkenaan dengan penerimaan kejelasan informasi dan alur prosedur penanganan pengaduan, akan disingkat menjadi variabel kejelasan informasi, kejelasan persyaratan pelayanan pengaduan akan disingkat menjadi variabel kejelasan persyaratan, kemampuan petugas memberikan pelayanan pengaduan akan disingkat menjadi variabel kemampuan petugas, dan ketersediaan sarana dan prasarana pengaduan akan disingkat menjadi variabel ketersediaan sarpras. Variabel output yang akan diproses adalah varibel Kepuasan pelayanan. Dalam proses menghasilkan nilai dari variabel output diperlukan empat tahapan yaitu pembentukan himpunan fuzzy (Fuzzifikasi), aplikasi fungsi impilkasi, komposisi aturan sampai proses penegasan (defuzzyfikasi).

\subsection{Pembentukan Himpunan Fuzzy (Fuzzifikasi)}

Proses fuzzifikasi berfungsi untuk mengubah masukan-masukan yang nilai kebenarannya bersifat pasti (crisp input) ke dalam bentuk fuzzy input. Proses penilaian tingkat kepuasan pelayanan pengaduan masyarakat berdasarkan 4 kriteria, diantaranya penerimaan kejelasan informasi dan alur prosedur penanganan pengaduan akan disingkat menjadi variabel kejelasan informasi, kejelasan persyaratan pelayanan pengaduan akan disingkat menjadi variabel kejelasan persyaratan, kemampuan petugas memberikan pelayanan pengaduan akan disingkat menjadi variabel kemampuan petugas dan ketersediaan sarana dan prasarana pengaduan akan disingkat menjadi variabel ketersediaan sarpras. Keempat kriteria tersebut yang digunakan sebagai variabel input fuzzy, sedangkan kepuasan pelayanan digunakan sebagai variabel output dari fuzzy. Perincian data dapat dilihat sebagai berikut:
Tabel 1. Variabel Input dan Output Fuzzy

\begin{tabular}{|l|l|c|c|}
\hline Fungsi & \multicolumn{1}{|c|}{$\begin{array}{c}\text { Nama } \\
\text { Variabel }\end{array}$} & $\begin{array}{c}\text { Semesta } \\
\text { Pembicar } \\
\text { aan }\end{array}$ & $\begin{array}{c}\text { Keterang } \\
\text { an }\end{array}$ \\
\hline $\begin{array}{l}\text { Variabel } \\
\text { input } \\
\text { fuzzy }\end{array}$ & $\begin{array}{l}\text { Kejelasan } \\
\text { Informasi }\end{array}$ & \begin{tabular}{c} 
Ke-100] \\
\cline { 2 - 4 }
\end{tabular} & $\begin{array}{c}\text { Angka } \\
\text { Penilaian }\end{array}$ \\
\cline { 2 - 4 } & $\begin{array}{l}\text { Kersyaratan } \\
\text { Petugampuan }\end{array}$ & {$[0-100]$} & $\begin{array}{c}\text { Angka } \\
\text { Penilaian }\end{array}$ \\
\cline { 2 - 4 } & $\begin{array}{l}\text { Ketersediaa } \\
\text { n Sarpras }\end{array}$ & {$[0-100]$} & $\begin{array}{c}\text { Angka } \\
\text { Penilaian }\end{array}$ \\
\hline $\begin{array}{l}\text { Variabel } \\
\text { output } \\
\text { fuzzy }\end{array}$ & $\begin{array}{l}\text { Kepuasan } \\
\text { Pelayanan }\end{array}$ & $\begin{array}{c}\text { Angka } \\
\text { Penilaian } \\
\text { Hasil }\end{array}$ \\
\hline
\end{tabular}

Selanjutnya dari setiap variabel akan ditentukan derajat keanggotaannya dengan menggunakan kurva segitiga, kurva bahu dan kurva trapesium dapat dilihat pada tabel berikut:

Tabel 2. Himpunan Fuzzy Penilaian Kepuasan Pelayanan

\begin{tabular}{|c|c|c|c|c|}
\hline $\begin{array}{c}\text { Nama } \\
\text { Variabel }\end{array}$ & $\begin{array}{c}\text { Himpun } \\
\text { an } \\
\text { Fuzzy }\end{array}$ & Domain & $\begin{array}{l}\text { Fungsi } \\
\text { Keangg } \\
\text { otaan }\end{array}$ & $\begin{array}{l}\text { Para } \\
\text { meter }\end{array}$ \\
\hline \multirow{3}{*}{$\begin{array}{c}\text { Kejelasan } \\
\text { Informasi } \\
\text { (Variabel } \\
\text { Input) }\end{array}$} & $\begin{array}{c}\text { Tidak } \\
\text { Memuas } \\
\text { kan }\end{array}$ & {$[0,75]$} & $\begin{array}{c}\text { Bahu } \\
\text { Kiri }\end{array}$ & $\begin{array}{c}(0 ; 60 ; \\
75)\end{array}$ \\
\hline & $\begin{array}{c}\text { Cukup } \\
\text { Memuas } \\
\text { kan }\end{array}$ & {$[60,90]$} & Segitiga & $\begin{array}{c}60 ; 75 \\
; 90)\end{array}$ \\
\hline & $\begin{array}{c}\text { Memuas } \\
\text { kan }\end{array}$ & {$[75,100]$} & $\begin{array}{l}\text { Bahu } \\
\text { Kanan }\end{array}$ & $\begin{array}{c}75 ; 90 \\
; 100)\end{array}$ \\
\hline \multirow{3}{*}{$\begin{array}{c}\text { Kejelasan } \\
\text { Persyarata } \\
\text { n (Variabel } \\
\text { Input) }\end{array}$} & $\begin{array}{c}\text { Tidak } \\
\text { Memuas } \\
\text { kan }\end{array}$ & {$[0,75]$} & $\begin{array}{c}\text { Bahu } \\
\text { Kiri }\end{array}$ & $\begin{array}{c}(0 ; 60 ; \\
75)\end{array}$ \\
\hline & $\begin{array}{l}\text { Cukup } \\
\text { Memuas } \\
\text { kan }\end{array}$ & {$[60,90]$} & Segitiga & $\begin{array}{c}(60 ; 75 \\
; 90)\end{array}$ \\
\hline & $\begin{array}{c}\text { Memuas } \\
\text { kan }\end{array}$ & {$[75,100]$} & $\begin{array}{l}\text { Bahu } \\
\text { Kanan }\end{array}$ & $\begin{array}{c}(75 ; 90 \\
; 100)\end{array}$ \\
\hline \multirow{3}{*}{$\begin{array}{c}\text { Kemampu } \\
\text { an } \\
\text { Petugas } \\
\text { (Variabel } \\
\text { Input) }\end{array}$} & $\begin{array}{c}\text { Tidak } \\
\text { Memuas } \\
\text { kan }\end{array}$ & {$[0,75]$} & $\begin{array}{c}\text { Bahu } \\
\text { Kiri }\end{array}$ & $\begin{array}{c}(0 ; 60 ; \\
75)\end{array}$ \\
\hline & $\begin{array}{l}\text { Cukup } \\
\text { Memuas } \\
\text { kan }\end{array}$ & {$[60,90]$} & Segitiga & $\begin{array}{c}60 ; 75 \\
; 90)\end{array}$ \\
\hline & $\begin{array}{c}\text { Memuas } \\
\text { kan }\end{array}$ & {$[75,100]$} & $\begin{array}{l}\text { Bahu } \\
\text { Kanan }\end{array}$ & $\begin{array}{c}(75 ; 90 \\
; 100)\end{array}$ \\
\hline \multirow{3}{*}{$\begin{array}{c}\text { Ketersedia } \\
\text { an } \\
\text { Sarpras } \\
\text { (Variabel } \\
\text { Input) }\end{array}$} & $\begin{array}{c}\text { Tidak } \\
\text { Memuas } \\
\text { kan }\end{array}$ & {$[0,75]$} & $\begin{array}{c}\text { Bahu } \\
\text { Kiri }\end{array}$ & $\begin{array}{c}(0 ; 60 ; \\
75)\end{array}$ \\
\hline & $\begin{array}{l}\text { Cukup } \\
\text { Memuas } \\
\text { kan }\end{array}$ & {$[60,90]$} & Segitiga & $\begin{array}{c}(60 ; 75 \\
; 90)\end{array}$ \\
\hline & $\begin{array}{c}\text { Memuas } \\
\text { kan }\end{array}$ & {$[75,100]$} & $\begin{array}{l}\text { Bahu } \\
\text { Kanan }\end{array}$ & $\begin{array}{c}75 ; 90 \\
; 100)\end{array}$ \\
\hline \multirow{2}{*}{$\begin{array}{l}\text { Kepuasan } \\
\text { Pelayanan } \\
\text { (Variabel } \\
\text { Output) }\end{array}$} & $\begin{array}{c}\text { Tidak } \\
\text { Memuas } \\
\text { kan }\end{array}$ & {$[0,75]$} & $\begin{array}{c}\text { Bahu } \\
\text { Kiri }\end{array}$ & $\begin{array}{c}(0 ; 50 ; \\
75)\end{array}$ \\
\hline & $\begin{array}{c}\text { Kurang } \\
\text { Memuas } \\
\text { kan }\end{array}$ & {$[50,150]$} & $\begin{array}{c}\text { Trapesiu } \\
\mathrm{m}\end{array}$ & $\begin{array}{c}50 ; 75 \\
; 125 ; 1 \\
50) \\
\end{array}$ \\
\hline
\end{tabular}




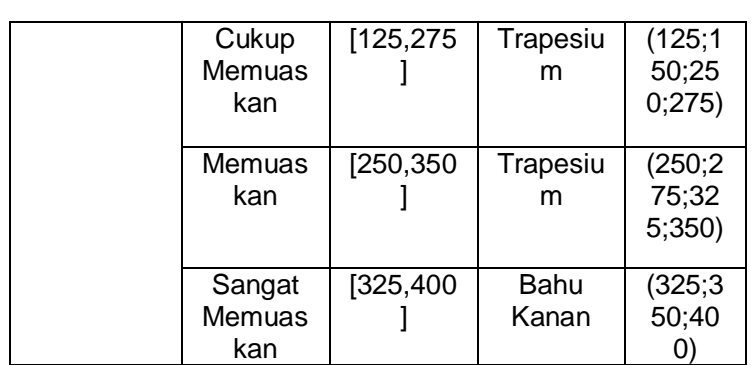

Berikut ini adalah grafik representasi derajat keanggotaan himpunan fuzzy penilaian kepuasan pelayanan:

a. Grafik Representasi Derajat Keanggotaan Variabel Kejelasan Informasi

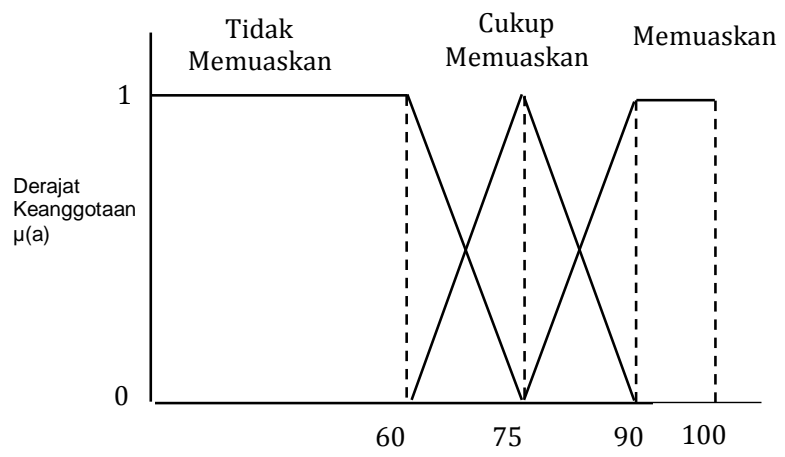

Gambar 1. Grafik Representasi Derajat Keanggotaan Variabel Kejelasan Informasi

Ekspresi untuk fungsi keanggotaan fuzzy untuk variabel Kejelasan Informasi bisa dilihat sebagai berikut : $\mu$ Tidak Memuaskan $[b]=$

$$
\left\{\begin{array}{lrl}
1 ; & b & \leq 60 \\
\frac{(75-b)}{(75-60)} ; & 60 \leq & b \leq 75 \\
0 ; & b & \geq 75
\end{array}\right.
$$

$\mu$ Cukup Memuaskan $[\mathrm{b}]=$

$$
\left\{\begin{array}{lr}
0 ; & b \leq 60 \text { dan } b \geq 90 \\
\frac{(b-60)}{(75-60)} ; & 60 \leq b \leq 75 \\
\frac{(90-b)}{(90-75)} ; & 75 \leq b \leq 90
\end{array}\right.
$$

$$
\begin{aligned}
& \mu \text { Memuaskan [b] }= \\
& \left\{\begin{array}{lrl}
0 ; & b & \leq 75 \\
\frac{(b-75)}{(90-75)} ; & 70 \leq b & \leq 90 \\
1 ; & b & \geq 90
\end{array}\right.
\end{aligned}
$$

Gambar 2. Ekspresi untuk fungsi keanggotaan fuzzy untuk variabel Kejelasan Informasi

\section{b. Grafik Representasi Derajat Keanggotaan Variabel Kejelasan Persyaratan}

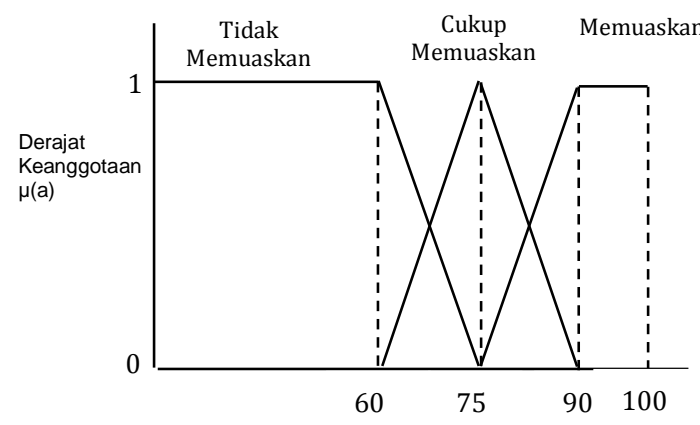

Gambar 2. Grafik Representasi Derajat Keanggotaan Variabel Kejelasan Persyaratan

Ekspresi untuk fungsi keanggotaan fuzzy untuk variabel Kejelasan Persyaratan bisa dilihat sebagai berikut :

$\mu$ Tidak Memuaskan $[b]=$

$$
\left\{\begin{array}{rlrl}
1 ; & b & \leq 60 \\
\frac{(75-b)}{(75-60)} ; & 60 \leq & b & \leq 75 \\
0 ; & b & \geq 75
\end{array}\right.
$$

$\mu$ Cukup Memuaskan $[\mathrm{b}]=$

$$
\left\{\begin{array}{lr}
0 ; & b \leq 60 \text { dan } b \geq 90 \\
\frac{(b-60)}{(75-60)} ; & 60 \leq b \leq 75 \\
\frac{(90-b)}{(90-75)} ; & 75 \leq b \leq 90
\end{array}\right.
$$

$\mu$ Memuaskan $[b]=$

$$
\left\{\begin{array}{lrl}
0 ; & b & \leq 75 \\
\frac{(b-75)}{(90-75)} ; & 70 \leq b & \leq 90 \\
1 ; & b & \geq 90
\end{array}\right.
$$

c. Grafik Representasi Derajat Keanggotaan Variabel Kemampuan Petugas

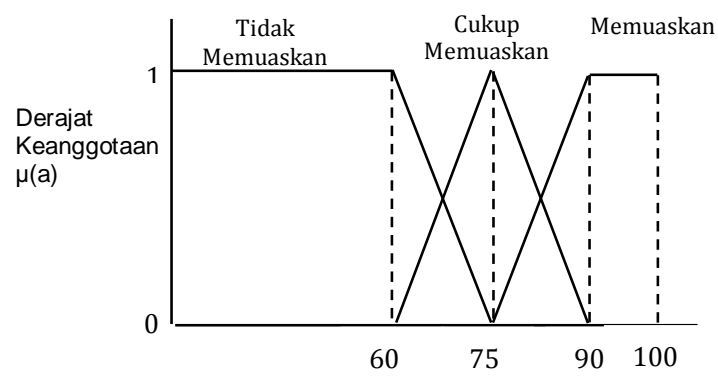

Gambar 3. Grafik Representasi Derajat Keanggotaan Variabel Kemampuan Petugas 
Ekspresi untuk fungsi keanggotaan fuzzy untuk variabel Kemampuan Petugas bisa dilihat sebagai berikut : $\mu$ Tidak Memuaskan $[b]=$

$$
\left\{\begin{array}{lrl}
1 ; & b & \leq 60 \\
\frac{(75-b)}{(75-60)} ; & 60 \leq & b \leq 75 \\
0 ; & b & \geq 75
\end{array}\right.
$$

$\mu$ Cukup Memuaskan $[\mathrm{b}]=$

$$
\left\{\begin{array}{lr}
0 ; & b \leq 60 \text { dan } b \geq 90 \\
\frac{(b-60)}{(75-60)} ; & 60 \leq b \leq 75 \\
\frac{(90-b)}{(90-75)} ; & 75 \leq b \leq 90
\end{array}\right.
$$$$
\mu \text { Memuaskan }[\mathrm{b}]=
$$$$
\left\{\begin{array}{lrl}
0 ; & b & \leq 75 \\
\frac{(b-75)}{(90-75)} ; & 70 \leq b \leq 90 \\
1 ; & b \geq 90
\end{array}\right.
$$

Gambar 4. Ekspresi untuk fungsi keanggotaan fuzzy untuk variabel Kemampuan Petugas

d. Grafik Representasi Derajat Keanggotaan Variabel Ketersediaan Sarnras

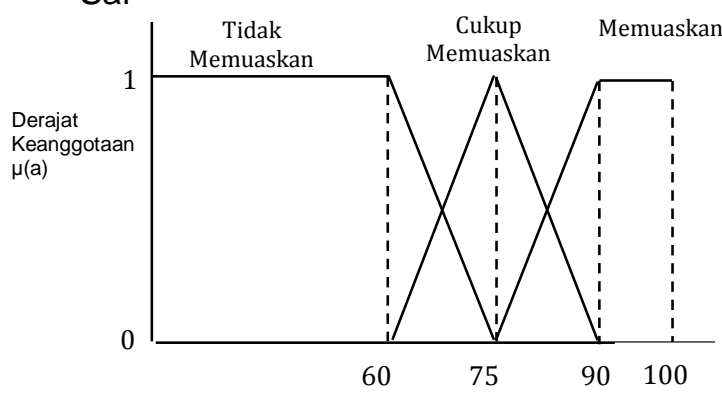

Gambar 4. Grafik Representasi Derajat Keanggotaan Variabel Ketersediaan Sarpras

Ekspresi untuk fungsi keanggotaan fuzzy untuk variabel Ketersediaan Sarpras bisa dilihat sebagai berikut :

$\mu$ Tidak Memuaskan $[b]=$

$$
\left\{\begin{array}{lr}
1 ; & b \leq 60 \\
\frac{(75-b)}{(75-60)} ; & 60 \leq b \leq 75 \\
0 ; & b \geq 75
\end{array}\right.
$$

$\mu$ Cukup Memuaskan $[b]=$

$$
\left\{\begin{array}{lr}
0 ; & b \leq 60 \text { dan } b \geq 90 \\
\frac{(b-60)}{(75-60)} ; & 60 \leq b \leq 75 \\
\frac{(90-b)}{(90-75)} ; & 75 \leq b \leq 90
\end{array}\right.
$$

$\mu$ Memuaskan $[\mathrm{b}]=$

$$
\left\{\begin{array}{lrl}
0 ; & b & \leq 75 \\
\frac{(b-75)}{(90-75)} ; & 70 \leq b \leq 90 \\
1 ; & b \geq 90
\end{array}\right.
$$
e. Grafik Representasi Derajat Keanggotaan Variabel Output Kepuasan Pelayanan

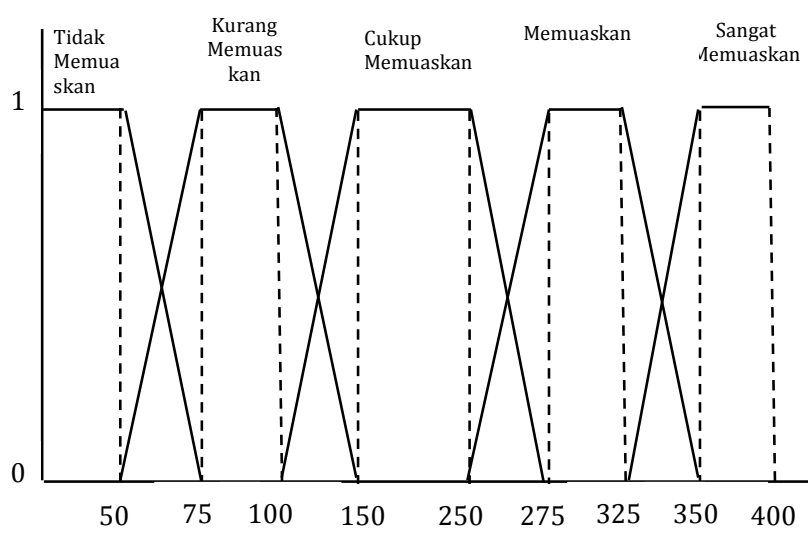

Gambar 5. Grafik Representasi Derajat Keanggotaan Variabel Output Kepuasan Pelayanan

Ekspresi untuk fungsi keanggotaan fuzzy untuk variabel Output Kepuasan layanan bisa dilihat sebagai berikut :

$\mu_{\text {Tidak Memuaskan }}[\mathrm{X}]=\left\{\begin{array}{lr}1 ; & x \leq 50 \\ \frac{(75-x)}{(75-50)} ; & 50 \leq x \leq 75 \\ 0 ; & x \geq 75\end{array}\right.$

$\mu$ Kurang Memuaskan $[\mathrm{x}]=$

$\left\{\begin{array}{lr}0 ; \quad x \leq 50 \text { atau } x \geq 150 \\ \frac{(x-50)}{(75-50)} ; & 50 \leq x \leq 75 \\ 1 ; & 75 \leq x \leq 100 \\ \frac{(150-x)}{(150-100)} ; & 100 \leq x \leq 150\end{array}\right.$

$\mu$ Cukup memuaskan $[\mathrm{x}]=$

$\left\{\begin{array}{cr}0 ; \quad x \leq 100 \text { atau } x \geq 275 \\ \frac{(x-100)}{(150-100)} ; & 100 \leq x \leq 150 \\ 1 ; & 150 \leq x \leq 250 \\ \frac{(275-x)}{(275-250)} ; & 250 \leq x \leq 275\end{array}\right.$

$\mu$ Memuaskan $[x]=$

$\left\{\begin{array}{lr}0 ; \quad x \leq 250 \text { atau } x \geq 350 \\ \frac{(x-250)}{(275-250)} ; & 250 \leq x \leq 275 \\ 1 ; & 275 \leq x \leq 325 \\ \frac{(350-x)}{(350-325)} ; & 325 \leq x \leq 350\end{array}\right.$ 
$\mu$ Sangat Memuaskan $[\mathrm{x}]=$

$\left\{\begin{array}{cc}0 ; & b \leq 325 \\ \frac{(x-325)}{(350-325)} ; & 325 \leq b \leq 350 \\ 1 ; & b \geq 350\end{array}\right.$

\subsubsection{Aplikasi Fungsi Implikasi}

Setelah pembentukan variabel pada himpunan fuzzy, maka dibentuk aturan yang bersesuian dengan penelitian yang dilakukan. Adapun aturan-aturan yang dimaksud adalah:

Aturan 1 : Jika Kejelasan Informasi Tidak Memuaskan dan Kejelasan Persyaratan Tidak Memuaskan dan Kemampuan Petugas Tidak Memuaskan dan Ketersediaan Sarpras Tidak Memuaskan maka Kepuasan Pelayanan Tidak Memuaskan

Aturan 2 : Jika Kejelasan Informasi Tidak Memuaskan Kejelasan Persyaratan Tidak Memuaskan dan Kemampuan Petugas Tidak Memuaskan dan Ketersediaan Sarpras Cukup Memuaskan maka Kepuasan Pelayanan Tidak Memuaskan

Aturan 3 : Jika Kejelasan Informasi Tidak Memuaskan dan Kejelasan Persyaratan Tidak Memuaskan dan Kemampuan Petugas Tidak Memuaskan dan Ketersediaan Sarpras Memuaskan maka Kepuasan Pelayanan Tidak Memuaskan

Aturan 4 : Jika Kejelasan Informasi Tidak Memuaskan dan Kejelasan Persyaratan Tidak Memuaskan dan Kemampuan Petugas Cukup Memuaskan dan Nilai Ketersediaan Sarpras Tidak Memuaskan maka Kepuasan Pelayanan Tidak Memuaskan

Aturan 5 : Jika Kejelasan Informasi Tidak Memuaskan dan Kejelasan Persyaratan Tidak Memuaskan dan Kemampuan Petugas Cukup Memuaskan dan Nilai Ketersediaan Sarpras Cukup Memuaskan maka Kepuasan Pelayanan Tidak Memuaskan

Aturan 6 : Jika Kejelasan Informasi Tidak Memuaskan dan Kejelasan Persyaratan Tidak Memuaskan dan Kemampuan Petugas Cukup Memuaskan dan
Ketersediaan Sarpras

Memuaskan maka Kepuasan

Pelayanan Cukup Memuaskan

Aturan 7 : Jika Kejelasan Informasi Tidak Memuaskan dan Kejelasan Persyaratan Tidak Memuaskan dan Kemampuan Petugas Memuaskan dan Ketersediaan Sarpras Tidak Memuaskan maka Kepuasan Pelayanan Tidak Memuaskan

Aturan 8 : Jika Kejelasan Informasi Tidak Memuaskan dan Kejelasan Persyaratan Tidak Memuaskan dan Kemampuan Petugas Memuaskan dan Nilai Ketersediaan Sarpras Cukup Memuaskan maka Kepuasan Pelayanan Cukup Memuaskan

Aturan 9 : Jika Kejelasan Informasi Tidak Memuaskan dan Kejelasan Persyaratan Tidak Memuaskan dan Kemampuan Petugas Memuaskan dan Nilai Ketersediaan Sarpras Memuaskan maka Kepuasan Pelayanan Cukup Memuaskan

Aturan 10 : Jika Kejelasan Informasi Cukup Memuaskan dan Kejelasan Persyaratan Cukup Memuaskan dan Kemampuan Petugas Cukup Memuaskan dan Ketersediaan Sarpras Cukup Memuaskan maka Kepuasan Pelayanan Cukup Memuaskan

Aturan 11 : Jika Kejelasan Informasi Cukup Memuaskan dan Kejelasan Persyaratan Cukup Memuaskan dan Kemampuan Petugas Memuaskan dan Ketersediaan Sarpras Memuaskan maka Kepuasan Pelayanan Memuaskan

Aturan 12 : Jika Kejelasan Informasi Cukup Memuaskan dan Kejelasan Persyaratan Memuaskan dan Kemampuan Petugas Memuaskan dan Nilai Ketersediaan Sarpras Memuaskan maka Kepuasan Pelayanan Sangat Memuaskan

Aturan 13 : Jika Kejelasan Informasi Memuaskan dan Kejelasan Persyaratan Memuaskan dan Kemampuan Petugas Memuaskan dan Nilai Ketersediaan Sarpras 
Memuaskan maka Kepuasan Pelayanan Sangat Memuaskan

Setelah aturan dibentuk maka, dilakukan aplikasi fungsi implikasi. Fungsi implikasi yang digunakan adalah MIN yang berarti tingkat keanggotaan yang didapat dari proses ini adalah nilai minimum dari variabel - variabel input untuk mendapatkan daerah fuzzy pada variabel kepusan pelayanan untuk masing - masing aturan.

Contoh kasus: Apa hasil dari Kepuasan Pelayanan Jika nilai Kejelasan Informasi 80 , Kejelasan Persyaratan 78, Kemampuan Petugas 80 dan Ketersediaan Sarpras 81.

Penyelesaian Kasus ini akan mengambil sample menggunakan aturan kesepuluh dan aturan keempat:

Contoh perhitungan menggunakan aturan kesepuluh:

IF Kepuasan_Pelayanan

Cukup_Memuaskan AND

Kejelasan_Informasi Cukup_Memuaskan

AND Kejelasan_Persyaratan

Cukup_Memuaskan AND

Ketersediaan_Sarpras Cukup_Memuaskan

THEN Kepuasan_Pelayanan

Cukup_Memuaskan

aPredikat $1=\pi$ Kepuasan_PelayananCukup_ Memuaskan $\cap$

mKejelasan_InformasiCukup_Memuaskan $\cap$

TKejelasan_PersyaratanCukup_Memuaska $\mathrm{n} \cap$

mKetersediaan_SarprasCukup_Memuaska $\mathrm{n}$

$=\mathrm{MIN}(\pi$ Kepuasan_PelayananCukup_Memu askan[80]; $\pi$

TKejelasan_InformasiCukup_Memuaskan[7 8];

mKejelasan_PersyaratanCukup_Memuaska $\mathrm{n}[80]$;

mKetersediaan_SarprasCukup_Memuaska $\mathrm{n}[81]$

$=\operatorname{MIN}(0,67 ; 0,2 ; 0 ; 0)$

$=0$

Bisa terlihat nilai terkecil ada di nilai 0 .

Contoh perhitungan menggunakan aturan kesebelas:

IF Kepuasan_Pelayanan

Cukup_Memuaskan AND

Kejelasan_Informasi Cukup_Memuaskan

AND Kejelasan_Persyaratan Memuaskan

AND Ketersediaan_Sarpras Memuaskan

THEN Kepuasan_Pelayanan Memuaskan
aPredikat1=TKepuasan_PelayananCukup_ Memuaskan $\cap$

TKKejelasan_InformasiCukup_Memuaskan $\cap$ mKejelasan_PersyaratanMemuaskan $\cap$ mKetersediaan_SarprasMemuaskan $=\mathrm{MIN}(\pi$ Kepuasan_PelayananCukup_Memu askan[80];ாKejelasan_InformasiCukup_Me muaskan[78];ாKejelasan_PersyaratanMem uaskan[80]; ;Ketersediaan_SarprasMemua skan[81]

$=\operatorname{MIN}(0,67 ; 0,2 ; 1 ; 1)$

$=0,2$

Bisa terlihat nilai terkecil ada di nilai 0,2.

\subsubsection{Komposisi Aturan}

Komposisi aturan fungsi implikasi menggunakan fungsi $M A X$ yaitu dengan cara mengambil nilai maksimum dari output aturan. Jika semua proposisi telah dievaluasi, maka output akan berisi suatu himpunan fuzzy yang merefleksikan konstribusi dari tiap-tiap proposisi. Pada metode MAX, solusi himpunan fuzzy diperoleh dengan cara mengambil nilai maksimum aturan,kemudian menggunakannya untuk memodifikasi daerah fuzzy, dan mengaplikasikannya ke output. Jika semua proposisi telah dievaluasi, kemudian output akan berisi suatu himpunan fuzzy yang merefleksikan konstribusi dari tiap-tiap proposisi, dapat ditulis sebagai berikut:

$$
\mu_{\mathrm{SF}}[\mathrm{XI}] \leftarrow \mathrm{MAX}\left(\mu_{\mathrm{SF}}[\mathrm{XI}], \mu_{\mathrm{KF}}[\mathrm{XI}]\right)
$$

$$
\text { dengan: }
$$

$\mu_{\mathrm{sf}}[\mathrm{XI}] \begin{aligned} & =\text { nilai keanggotaan solusi fuzzy } \\ & \text { sampai aturan ke-I }\end{aligned}$

$\mu_{\mathrm{KF}}[\mathrm{XI}] \begin{aligned} & =\text { nilai keanggotaan konsekuen fuzzy } \\ & \text { sampai aturan ke-I }\end{aligned}$

Gambar 6. Komposisi Aturan MAX

\subsubsection{Proses Defuzzifikasi}

Proses defuzzifikasi adalah mengubah fuzzy output menjadi nilai tegas berdasarkan fungsi keanggotaan yang telah ditentukan. Proses defuzzifikasi menggunakan Metode Centroid. Proses defuzzifikasi digambarkan seperti berikut: 
Defuzzifikasi

$$
\begin{aligned}
& = \\
& \frac{\left(\begin{array}{c}
(\alpha \operatorname{Pred} 4 * \mathrm{x} 4)+(\alpha \operatorname{Pred} 4 * \mathrm{x} 4)+(\alpha \operatorname{Pred} 8 * \mathrm{x} 8)+(\alpha \operatorname{Pred} 8 * \mathrm{x} 8) \\
+(\alpha \operatorname{Pred} 12 * \mathrm{x} 12)+(\alpha \operatorname{Pred} 12 * \mathrm{x} 12)+(\alpha \operatorname{Pred} 16 * \mathrm{x} 16)
\end{array}\right)}{(\alpha \text { Pred } 4+\alpha \text { Pred } 4+\alpha \text { Pred } 8+\alpha \text { Pred } 8} \\
& +\alpha \text { Pred } 12+\alpha \text { Pred } 12+\alpha \text { Pred16) } \\
& =\frac{\left(\begin{array}{c}
(0,2 * 255)+(0,2 * 345)+(0,67 * 266,75)+(0,67 * 266,75)+(0,2 * 255) \\
+(0,2 * 345)+(0,33 * 33,25)
\end{array}\right)}{(0,2+0,2+0,67+0,67+0,2+0,2+0,33)} \\
& =\frac{785,8}{2.47}=318,137
\end{aligned}
$$

Pada perhitungan diatas dapat terlihat bahwa hasil kepuasan pelayanan bernilai 318,137 dan ada di derajat keanggotaan Memuaskan.

\section{Kesimpulan}

Penggunaan metode mamdani untuk penilaian tingkat kepuasan pelayananan terhadap pengaduan masyarakat melalui empat proses mulai dari Pembentukan Himpunan Fuzzy (Fuzzifikasi), Aplikasi Fungsi Implikasi, Komposisi Aturan dan Defuzzifikasi. Hasilnya terlihat bahwa dengan menggunakan model fuzzy mamdani dapat memperlihatkan aturan keterhubungan antara variabel input yaitu kejelasan informasi, kejelasan persyaratan, kemampuan petugas dan ketersediaan sarpras sehingga menghasilkan output nilai untuk kepuasan pelayanan. Penelitian ini sudah membuktikan korelasi variabelvariabel tersebut dalam menentukan hasil kepuasan pelayanan pengaduan masyarakat. Pengembangan penelitian ini kedepan nya akan diuji coba kembali dengan menambahkan lebih banyak variabel input dan akan dibuat sebuah interface untuk memudahkan pemprosesan hasil penilaian kualitas pelayanan pengaduan masyarakat.

\section{Referensi}

Cronin, J. J., \& Taylor, S. . (1992). Measuring Service Quality: A Reexamination and Extension. Journal of Marketing, 55-68.

FC, L. L. Van, \& Lisnawita. (2017). Analisis Kepuasan Pelanggan Terhadap Pelayanan Purnajual CV . Family Menggunakan Metode Fuzzy-Logic. Jurnal Inovtek Polbeng-Seri
Informatika, 2(1), 64-67.

Jusia, P. A., \& Yani, H. (2017). Model Kepuasan Mahasiswa Terhadap Sistem Pelayanan Administrasi Akademik dan Kemahasiswaan (BAAK) dengan Fuzzy Inference System Metode Mamdani Pada STIKOM Dinamika Bangsa Jambi. Seminar Nasional IPTEK Terapan (SENIT), 1-10.

KEP/25/M.PAN/2/2004. (2004). KEPMENPAN Tentang Pedoman Umum Penyusunan Indeks Kepuasan Masyarakat Unit Pelayanan Instansi Pemerintah.

Kotler, P. (2003). Marketing Management. New Jersey: Prentice Hall.

Kusumadewi, S. (2002). Analisis dan Desain Sistem Fuzzy Menggunakan Toolbox Matlab. Yogyakarta: Graha IImu.

Kusumadewi, S., \& Purnomo, H. (2004). Aplikasi Logika Fuzzy Untuk Pendukung Keputusan. Yogyakarta: Graha IImu.

Nuraida, Iryanto, \& Sebayang, D. (2013). Analisis Tingkat Kepuasan Konsumen Berdaarkan Pelayanan, Harga, dan Kulaitas Makanan Menggunakan Fuzzy Mamdani (Studi Kasus pada Restoran Cepat Saji CFC Marelan). Saintia Matematika, 1(6), 543-555.

Putri, N. S., Sumanto, Sari, E. P., \& Ispandi. (2014). Metode Fuzzy Untuk Analisa Pngaruh Kepuasan Nasabah Terhadap Kinerja Pelayanan Teller 
(Studi Kasus: PT. Bank DKI Cabang Walikota Jakarta Timur). SNIPTEK, 231-238.

Sutojo, T., Mulyanto, E., \& Suhartono, V. (2011). Kecerdasan Buatan. Yogyakarta: Andi.

Tarigan, S. Y. B., Tobing, M. L., \& Situmorang, Z. (2017). Mengukur Tingkat Kepuasan Mahasiswa Terhadap Kinerja Dosen Menggunakan Metode Fuzzy Mamdani. Seminar Nasional Teknologi Informatika (Semantika), 163-168.

Williams, C., \& Buswell, J. (2003). Service Quality in Leisure and Tourism. Wallingford, UK: Cabi Publishing.

Wiratno, D. H. (1998). Pengukuran Tingkat Kepuasan Konsumen Dengan Servqual. Wahana, 1(1).

Zadeh, L. A. (1975). Fuzzy Sets and Their Applications to Cognitive and Decision Processes. Inc. New York: Academic Press. 